\title{
Musculoskeletal Anatomy by Self-examination: A Learners Satisfaction Survey at the 2018 PANLAR Meeting
}

Issued:

February 9, 2021 


\section{Authors}

Cristina Hernández-Diaz, MD

Instituto Nacional de Rehabilitación

"Luis Guillermo Ibarra Ibarra"

cristy_hernandez@prodigy.net.mx

ORCID: 0000-0001-9020-3722

Miguel Angel Saavedra, MD

Hospital "Antonio Fraga Mouret,"

La Raza National Medical Center

miansaavsa@gmail.com

ORCID: 0000-0003-0687-9944

Virginia Pascual-Ramos, MD

Instituto Nacional de Ciencias Médicas

y Nutrición Salvador Zubirán

virtichu@gmail.com

ORCID: 0000-0002-7368-498X
Robert A. Kalish, MD

Tufts Medical Center and Associate Professor of Medicine, Tufts University

School of Medicine, Boston

rkalish@tuftsmedicalcenter.org

ORCID: 0000-0002-1638-4243

Juan J. Canoso, MD, ABC Medical Center, Mexico City; Tufts University School of Medicine, Boston jcanoso@gmail.com ORCID: 0000-0002-1185-8294 


\section{SCIENTIFIC ARTICLE}

\section{Musculoskeletal Anatomy by Self-examination: A Learners Satisfaction Survey at the 2018 PANLAR Meeting}




\section{in Spanish}

\section{Introducción}

La anatomía musculoesquelética (AME) es la base del examen físico reumatológico. La AME, en asociación con la ecografía, son esenciales en la formación de reumatólogos. Los autores desarrollaron una pedagogía centrada en el alumno, la AME por autoexamen (AMEA), que combina la autoinspección, palpación y percepción, para suplementar pedagogías estándar de AME.

\section{Objetivo}

Determinar la satisfacción de los participantes con AMEA en tres talleres realizados en el Congreso PANLAR 2018.

\section{Métodos}

Los ejercicios de AMEA incluyen una descripción de elementos anatómicos críticos, su autoidentificación por inspección, palpación y autopercepción, el efecto del movimiento o la contracción muscular en éstos y una revisión de su importancia clínica. Evaluamos diecisiete ejercicios para determinar la satisfacción de los participantes; seis de hombro y codo, cinco de mano y muñeca y seis de extremidades inferiores. Antes de los talleres, los participantes fueron invitados a completar una encuesta voluntaria y anónima de satisfacción con el nuevo método utilizando un cuestionario y una escala visual análoga. Los resultados se expresaron con estadística descriptiva.

\section{Resultados}

Un total de 280 asistentes participaron en los talleres, 100 en el primero, 120 en el segundo y 60 en el tercero. Noventa, 100 y 37 participantes, respectivamente, completaron la encuesta. Reumatólogos, otros profesionales y residentes, independientemente de las regiones anatómicas, expresaron una satisfacción con el método mayor del $80 \%$.

\section{Conclusión}

En esta sencilla encuesta, la satisfacción de los participantes con AMEA fue alta y estudios formales sobre su utilidad parecen justificados. 


\section{Introduction}

In rheumatology, musculoskeletal (MSK) anatomy is the basis of the physical examination. Living MSK anatomy methods, plus ultrasonography, are eminently suited for rheumatology training. The authors developed a learner-centred pedagogy, MSK anatomy by self-examination (MSKASE), which combines self-inspection, palpation, and perception, to supplement current MSK anatomy learning methods.

\section{Objective}

To survey the learner satisfaction with MSKASE in three workshops held at the 2018 PANLAR meeting.

\section{Methods}

MSKASE exercises include a description of critical anatomical items, their self-identification by inspection, palpation, and perception, the effect of motion or muscle contraction on these items, and a review of their clinical significance. We evaluated seventeen exercises for learner satisfaction; six dealt with the shoulder and elbow, five with the hand and wrist, and six with the lower extremities. The lecturing instructor invited the participants to complete at the end of the workshops a voluntary, anonymous survey of their reaction to MSKASE using a simple questionnaire and a visual analogue scale (VAS). The results were expressed with descriptive statistics.

\section{Results}

A total of 280 meeting attendees participated in the workshops, 100 in the first, 120 in the second, and 60 in the third. Ninety, 100, and 37 participants, respectively, completed the survey. Rheumatologists, other professionals, and trainees, irrespective of the anatomical regions, expressed satisfaction with the method of over $80 \%$. Additionally, we summarized informal comments made by the participants.

\section{Conclusion}

The participant's rating of MSKASE was high, and formal studies of the method appear warranted. 


\section{Introdução}

Na reumatologia, a anatomia musculoesquelética (MSK) é a base do exame físico. Os métodos vivos da anatomia MSK, em associação com a ultrassonografia, são eminentemente adequados para o treinamento em reumatologia. Os autores desenvolveram uma pedagogia centrada no aluno, anatomia MSK por autoexame (MSKASE), que combina autoinspeção, auto-palpação e autopercepção, como um auxílio aos métodos atuais da anatomia MSK.

\section{Objetivo}

Para determinar a satisfação do aluno com a pedagogia MSKASE em três workshops realizados na reunião PANLAR de 2018.

\section{Método}

Os exercícios MSKASE incluem uma descrição de itens anatômicos críticos, sua auto-identificação por inspeção, palpação e percepção, o efeito do movimento ou contração muscular sobre esses itens e seu significado clínico. Avaliamos dezessete exercícios; seis lidaram com o ombro e cotovelo, cinco com a mão e punho e seis com extremidades inferiores. Antes das oficinas, as participantes foram convidados a preencher, os final das oficinas, uma pesquisa voluntária ao anônima sobre sua reação a esse novo método e meio de um questionário e uma escala por analógica. Os resultados foram expressosvisbiał estatística descritiva.

\section{Resultados}

No total, 280 participantes da reunião participaram dos workshops, 100 no primeiro, 120 no segundo e 60 no terceiro. Noventa, 100 e 37 participantes, respectivamente, completaram a pesquisa de satisfação. Reumatologistas, outros profissionais e estagiários, independentemente das regiões anatômicas, expressaram satisfação com o método em mais de $80 \%$. Além disso, resumimos comentários informais feitos pelos participantes.

\section{Conclusão}

A satisfação dos participantes com MSKASE foi alta, e estudos sobre sua utilidade parecem justificados. 


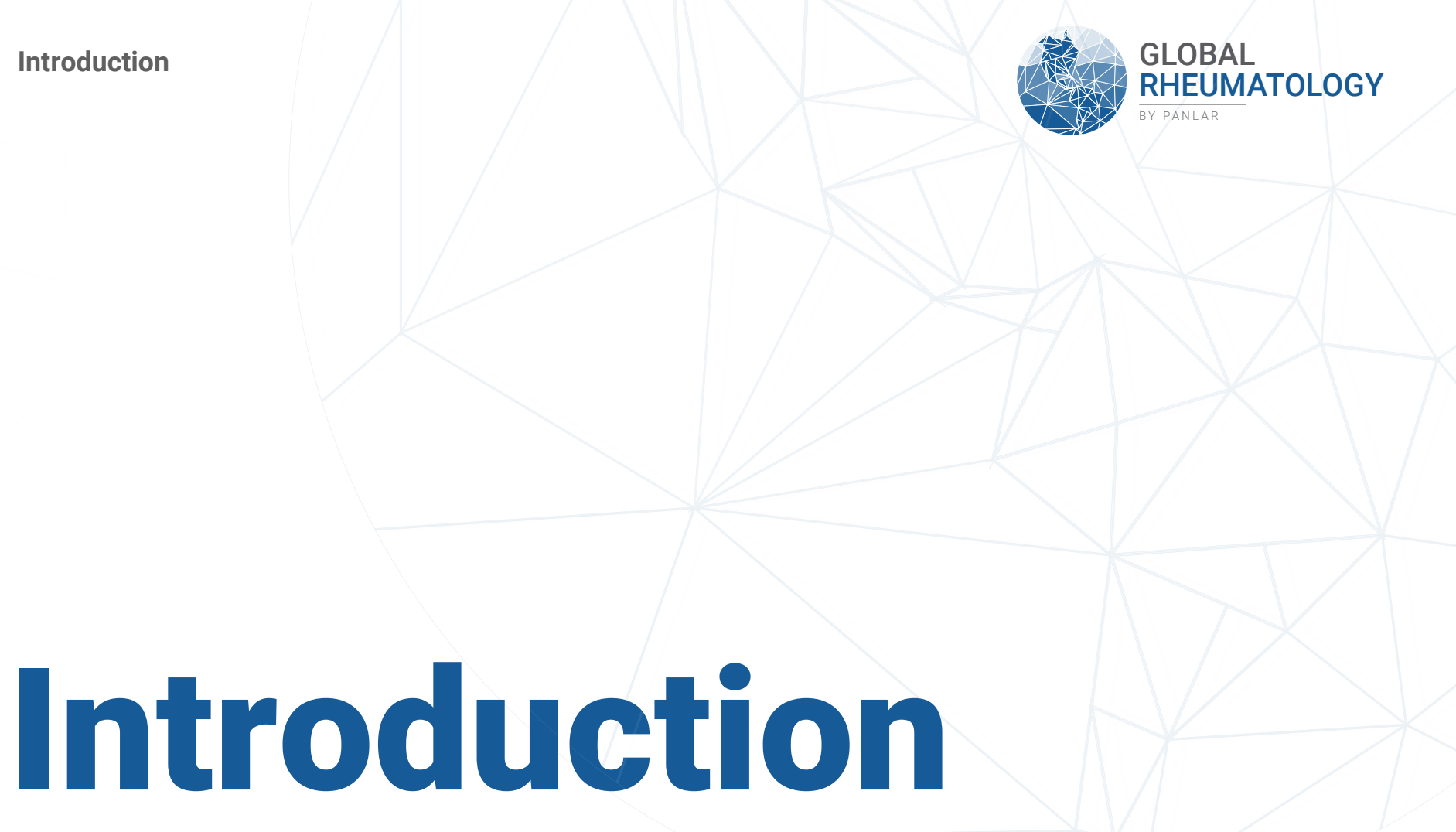

The teaching of anatomy in medical school was already in a flux state and may now be in crisis due to the COVID-19 pandemic. Larger student classes and a scarcity of suitable cadavers for dissection led to pedagogies such as realistic anatomical models, plastinated specimens, 3-D reconstructions based on cadaveric samples, computed tomography (CT) imaging, magnetic resonance imaging (MRI) virtual dissection, and medical simulation [1-4]. Live anatomy teaching advanced by model body painting, peer cross-examination [5-7], and the use of ultrasonography (US) [8]. Of these pedagogies, the latter two eminently applied to postgraduate teaching in musculoskeletal (MSK)-based subspecialties such as neurology, physical therapy, rehabilitation medicine, rheumatology, and sports medicine [9-11]. Now, the COVID-19 pandemic gives an additional impulse to virtual teaching and creates a need for innovative pedagogies. While cadaver dissection remains the acknowledged bedrock of the medical sciences and may lead to the best results [12], there are indications that students indeed prefer 3-D visualization methods as compared to cadaver dissections and books [3].

Old textbooks of surface anatomy recommended self-examination to practice what students learned in the dissection sessions [13]. However, as a flexible ancillary learner-centred method at the medical school and postgraduate levels, MSK anatomy by self-examination (MSKASE) has only recently been proposed [14]. Self-examination allows an exquisite perception of reachable MSK parts, including some nerves and arteries. Also, the method has the embedded strength of self-perception. This unique feature of MSKASE may help understand the effect of motion in complex areas, enhance spatial appreciation, and as a result, increase recollection [15]. A potential additional benefit is that the exercises may be taught and assessed by video conferencing. In this survey, the authors did not compare the new method to other methods. Their goals were much more limited, to glimpse the participant's satisfaction with a unique pedagogy that it is directed to self. 


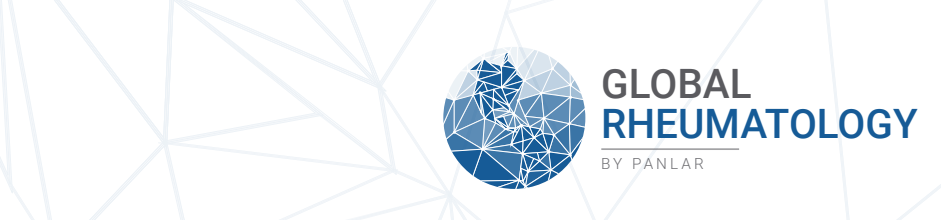

Material and Methods

The authors were invited to hold three clinical anatomy workshops at the 2018 PANLAR (Pan American League of Associations for Rheumatology) Meeting in Buenos Aires, Argentina. The workshops were free and open to all. This fortunate circumstance allowed the authors to evaluate the satisfaction with MSKASE by 102 rheumatologists, six other MSK anatomy-related subspecialists; 50 rheumatology trainees; and 60 unstated subspecialty trainees. Each of the three workshops, held on consecutive days, had a duration of 1 hour and 45 minutes. At the beginning of each session, attendees were invited to fill, following the workshop, a de-identified simple evaluation form, which included their speciality, level of training (trainees or specialists), and perception of the method. Demographic characteristics, such as age and sex, were not inquired about. The three instructors proposed the survey content, which was an extension of a pilot survey at the Anatomy Department, National Autonomous University of Mexico (UNAM), which failed because only eleven students participated. The instructors used a six-component questionnaire.

The components were: 1. Attendees' perception that learning materials were helpful. 2. Attendees' perception that the method helps incorporate knowledge of clinical anatomy. 3. Attendees' perception that there was adequate time for the exercises. 4. Attendees' perception that the acquired knowledge and skills are relevant. 5 . Attendees' perception that he/she would be able to apply the acquired knowledge and skills. 6 . Attendees' perception that they would recommend peers to attend a similar MSKASE seminar. For each component, a five-point Likert scale was used to capture the amplitude of attendees' perceptions. Based on the distribution of the patients' responses, scale responses were 
further reduced into three categories, as follows: strongly disagree/disagree, neutral, and agree/strongly agree (Figure 1). Finally, a visual analog scale (VAS) was used for an overall rating of workshop satisfaction (Figure 2). Results were expressed with descriptive statistics. To balance the presentations, each of the three instructors led one of the seminars. The other two assisted the participants in identifying in their bodies the anatomical items being discussed. The instructors (CH-D, MÁS) had a 3-year training in clinical anatomy from 2007 to 2010 under the direction of JJC. They gained substantial experience conducting through the Americas clinical anatomy seminars based on instructors' and trainees' cross-examination. Thus, although the teaching method was not formally standardized, the three instructors' shared training and experience likely resulted in a uniform teaching style.

Table 1 indicates the shoulder and elbow, wrist and hand, and lower extremity items or functions and their clinical relevance discussed in the workshops. None of these exercises requires privacy in their execution. To give some examples, Exercise 1 explores a possible neck or cervical spine source of shoulder pain. To this end, the participants bent the neck forward, backward, to the sides, and rotated the head. In muscle contracture, bending or turning the neck contralaterally would cause the pain. In contrast, homolateral motions would trigger radicular, facet joint, or uncovertebral joint pain. If these motions did not cause the pain, then the various shoulder manoeuvres will likely establish its origin. Exercise 2, which in clinical practice would follow Exercise 1 , is the full abduction of the extended extremity in the scapular plane. Pain in the mid-range of elevation suggests a rotator cuff tendinopathy.
Pain beginning near-total elevation indicates that the faulty structure is the acromioclavicular or the sternoclavicular joint. The defective structure is indicated by tenderness on pressing one of these joints. Exercise 8 explores by palpation of the four bone eminences where the transverse carpal ligament inserts. These landmarks, plus the identification of the tendon of palmaris longus and flexor carpi radialis, allow a safe blind steroid injection in the carpal tunnel syndrome. Exercise 12 detects the origin of the hip abductor muscles. In the standing position, participants place the first web space (between the thumb and the index) of one hand between the greater trochanter and the pelvic rim, index to the front, and thumb to the back. Then, participants take a few steps or stand on one leg at a time. The index will feel the tensor fasciae latae, the web gluteus medius, and the index gluteus maximus. 
Results

Approximately sixty participants were expected at each workshop; however, 100 attended the first, 120 the second, and 60 the third, which took place the last day of the meeting as its ending event when many attendants had left.

Ninety (90\%) participants in the first workshop returned the evaluation form, 100 (83\%) in the second, and 37 (62\%) in the third. Figure 1 is a bar graph that depicts the participant's perception statements per anatomical region based on the three-point reduction of the five-point Likert scale used. The authors felt that such reduction was advisable because most participants agreed or strongly agreed with the new method regardless of the anatomical region and lecturer. Figure 2 is a radar chart visualization that provides the global rating per anatomical region by specialists (102 rheumatologists and six other MSK-interested specialists), rheumatology trainees (50), and other trainees who did not mention the subspecialty (69). In all instances, regardless of the anatomical region -and therefore irrespective of the lecturer- and type of participants -professionals and trainees- the satisfaction rate was uniformly over $80 \mathrm{~mm}$ out of a possible $100 \mathrm{~mm}$.

The room's theatre arrangement, with the podium at the front and the chairs arranged in rows, plus the unexpectedly large number of attendees in the first two workshops, created logistical problems during the lectures that the assistants solved rushing around the room between the chair rows. 
Results

Figure 1

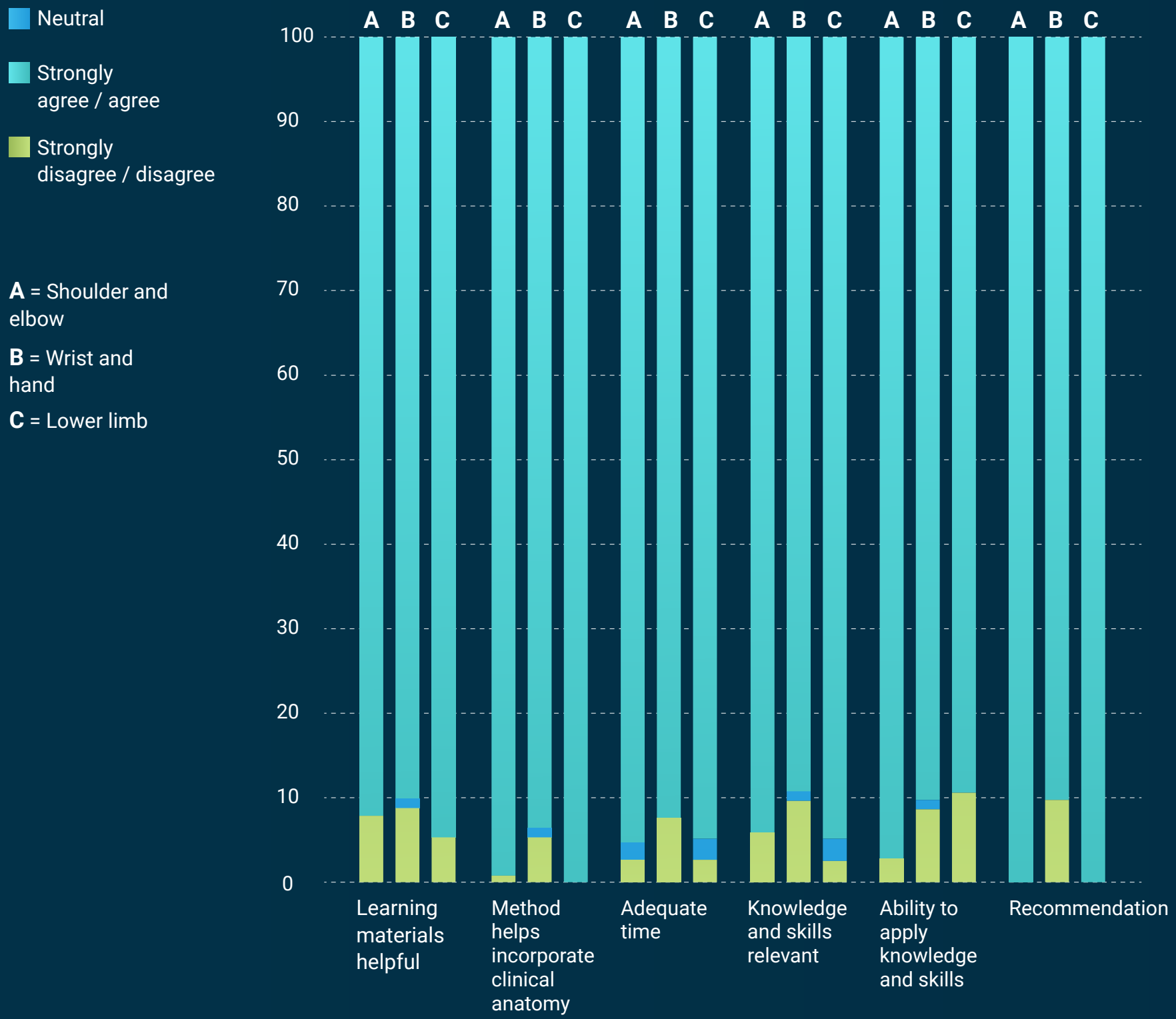


Results

Figure 2

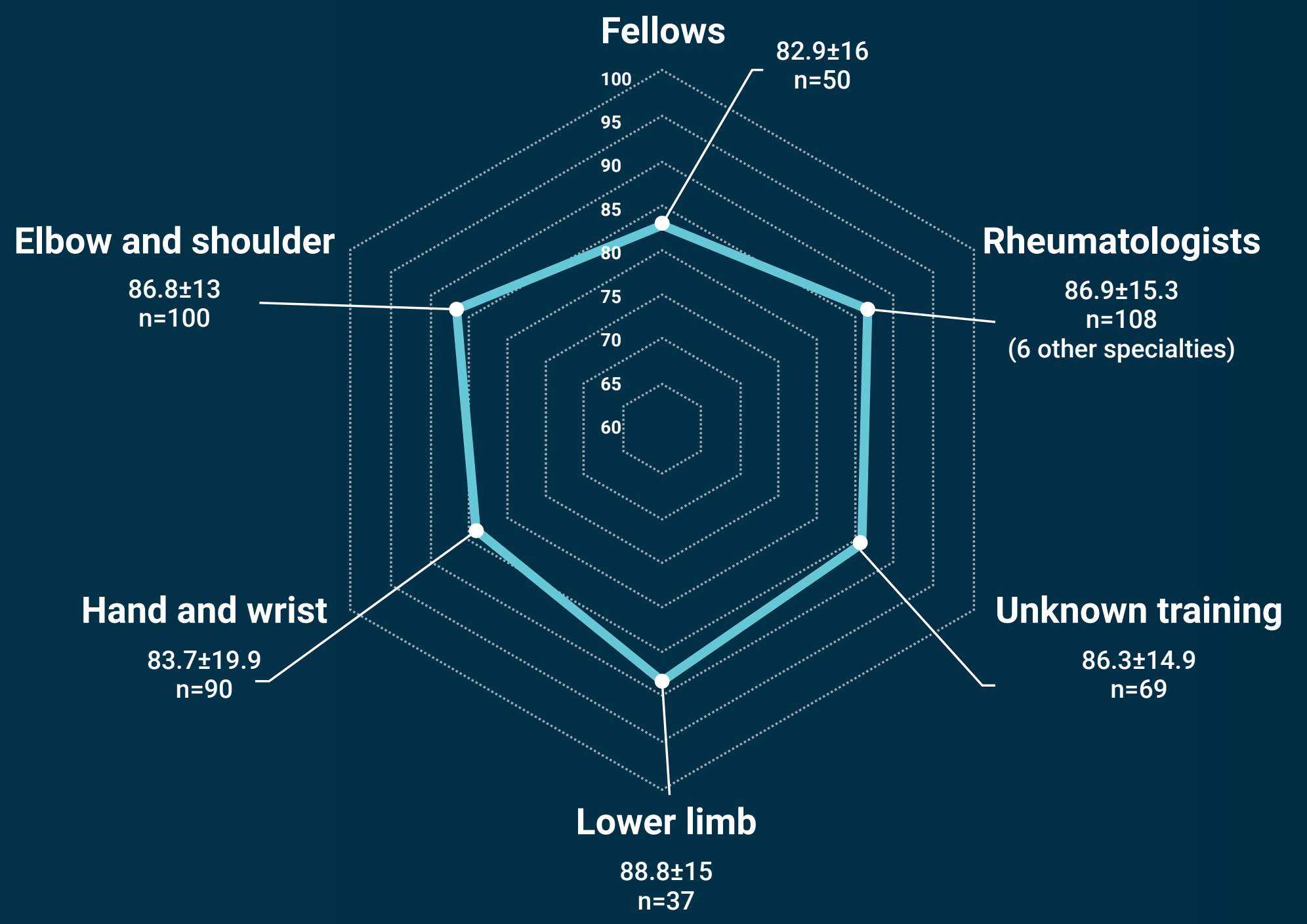




\section{Table 1: Seventeen Anatomical Items or Functions Explored in Self-Examination Exercises}

\begin{tabular}{|c|c|c|c|}
\hline Region & Items explored & Self-maneuver & Clinical relevance \\
\hline \multirow{6}{*}{$\begin{array}{l}\text { Shoulder } \\
\text { and elbow }\end{array}$} & Cervical or shoulder pain? & $\begin{array}{l}\text { Move your neck forward, backward, } \\
\text { to the sides, and rotate it }\end{array}$ & $\begin{array}{l}\text { Differential diagnosis between a } \\
\text { cervical or a shoulder origin of pain }\end{array}$ \\
\hline & Martin's maneuver & $\begin{array}{l}\text { Abduct the arm with the elbow flexed } \\
90 \text { degrees in internal and then in } \\
\text { external rotation }\end{array}$ & $\begin{array}{l}\text { Full arm abduction requires external } \\
\text { humeral rotation }\end{array}$ \\
\hline & Shoulder abduction & $\begin{array}{l}\text { Abduct the extended upper extremity } \\
\text { in the scapular plane }\end{array}$ & $\begin{array}{l}\text { Pain in mid-abduction usually indicates } \\
\text { a rotator cuff pathology }\end{array}$ \\
\hline & Shoulder abduction & $\begin{array}{l}\text { Abduct the extended upper extremity } \\
\text { in the scapular plane }\end{array}$ & $\begin{array}{l}\text { Pain that mounts nearing full abduction } \\
\text { suggests an acromioclavicular or } \\
\text { sternoclavicular joint origin }\end{array}$ \\
\hline & The walls of the axilla & $\begin{array}{l}\text { Bring your hand behind your head. } \\
\text { Identify the muscles making up the } \\
\text { anterior, the posterior, the medial, and } \\
\text { the lateral walls of the axilla }\end{array}$ & $\begin{array}{l}\text { Understand the anatomy: P, PM, CB, SA, } \\
\text { LD, TM muscles, scapula, humeral head }\end{array}$ \\
\hline & The carrying angle & $\begin{array}{l}\text { Stand up with the extended extremity at } \\
\text { your side, palm to the front. Your hand } \\
\text { separates from your thigh }\end{array}$ & $\begin{array}{l}\text { This feature of the elbow, if not required, } \\
\text { is compensated by internal rotation of } \\
\text { the humerus }\end{array}$ \\
\hline
\end{tabular}

\begin{tabular}{|c|c|c|c|}
\hline \multirow{5}{*}{$\begin{array}{l}\text { Wrist and } \\
\text { hand }\end{array}$} & Pronation and supination & $\begin{array}{l}\text { Pronate (a) around your ulna, and then } \\
\text { (b) around an axis that extends from } \\
\text { the capitulum to the chuck\# }\end{array}$ & $\begin{array}{l}\text { When force is needed, use (a); } \\
\text { for precision, use (b) }\end{array}$ \\
\hline & $\begin{array}{l}\text { Bone attachments of the } \\
\text { transverse carpal ligament } \\
\text { (TCL) }\end{array}$ & $\begin{array}{l}\text { Identify, between the thumb and index } \\
\text { of your opposite hand, the four bone } \\
\text { stays of the TCL }\end{array}$ & $\begin{array}{l}\text { The TCL binds the carpal tunnel } \\
\text { anteriorly }\end{array}$ \\
\hline & $\begin{array}{l}\text { The action of the } 1 \text { st dorsal } \\
\text { interosseous muscle (DIT1). } \\
\text { The principle applies to all } \\
\text { digits }\end{array}$ & $\begin{array}{l}\text { Place your index on the axis of flexion }(\mathrm{F}) \\
\text { of the opposite } 2 \text { nd MCP joint. Follow } \\
\text { the edge of the DIT1 to its insertion on } \\
\text { the proximal phalanx of the index }\end{array}$ & $\begin{array}{l}\text { The insertion site is palmar to } F \text {, and } \\
\text { therefore the DIT1 flexes the MCP joint. } \\
\text { (required for precision movements of } \\
\text { the index) }\end{array}$ \\
\hline & $\begin{array}{l}\text { The lateral bands of the } \\
\text { extensor apparatus at the } \\
\text { proximal phalanx }\end{array}$ & $\begin{array}{l}\text { Place your index and thumb at the sides } \\
\text { of the proximal phalanx of the opposite } \\
\text { ring finger. Flex and extend the PIPJ }\end{array}$ & $\begin{array}{l}\text { The lateral bands tighten and advance } \\
\text { palmarly with PIP flexion, I and dorsally } \\
\text { with PIPJ extension }\end{array}$ \\
\hline & The thumb motions & $\begin{array}{l}\text { Hold a tennis ball in the hollow of your hand. } \\
\text { Press ball with thumb and is flexion. Release it } \\
\text { and is extension. Follow surface toward index } \\
\text { and is adduction. Follow surface toward little } \\
\text { finger and is abduction }\end{array}$ & $\begin{array}{l}\text { This self-exercise is useful to } \\
\text { demonstratethe complex motions of } \\
\text { the thumb realistically }\end{array}$ \\
\hline
\end{tabular}




\section{Table 1: Seventeen Anatomical Items or Functions Explored in Self-Examination Exercises}

\begin{tabular}{|c|c|c|c|}
\hline Region & Items explored & Self-maneuver & Clinical relevance \\
\hline \multirow{6}{*}{$\begin{array}{l}\text { Lower } \\
\text { extremity }\end{array}$} & Hip abductors & $\begin{array}{l}\text { Walk placing your first webs just distal } \\
\text { to the iliac crests }\end{array}$ & $\begin{array}{l}\text { During the support phase, you'll feel the contraction } \\
\text { of tensor fasciae latae beneath your indexes, } \\
\text { gluteus medius beneath the web edge, and gluteus } \\
\text { maximus beneath your thumbs }\end{array}$ \\
\hline & Ischial tuberosity & $\begin{array}{l}\text { Sit on your hands, identify the ischial } \\
\text { tuberosities, and attempt to stand up }\end{array}$ & $\begin{array}{l}\text { Feel the gluteus maximus contracting } \\
\text { under your fingers. This muscle cushion } \\
\text { prevents sores }\end{array}$ \\
\hline & $\begin{array}{l}\text { Quadriceps muscle } \\
\text { during gait }\end{array}$ & $\begin{array}{l}\text { Walk some steps while you embrace } \\
\text { your quadriceps }\end{array}$ & $\begin{array}{l}\text { From heel strike to mid-stance the } \\
\text { quadriceps muscle contracts }\end{array}$ \\
\hline & $\begin{array}{l}\text { Hamstring muscles during } \\
\text { gait }\end{array}$ & $\begin{array}{l}\text { Walk some steps while you embrace your } \\
\text { hamstrings }\end{array}$ & $\begin{array}{l}\text { From heel strike through early stance the } \\
\text { hamstring muscles contract }\end{array}$ \\
\hline & $\begin{array}{l}\text { Anatomical landmarks of } \\
\text { the medial knee }\end{array}$ & $\begin{array}{l}\text { While sitting, rest one leg over the } \\
\text { opposite knee and palpate the tendons } \\
\text { where the thigh meets the leg }\end{array}$ & $\begin{array}{l}\text { Superficially, G; St about } 1.5 \mathrm{~cm} \text { below. } \\
\text { Both tendons meet the tibia at the } \\
\text { anserine entheses }\end{array}$ \\
\hline & The iliotibial band & $\begin{array}{l}\text { While sitting, find in your thigh a lateral } \\
\text { tendinous edge. As you attempt to } \\
\text { stand, this edge does not connect with } \\
\text { the patella }\end{array}$ & $\begin{array}{l}\text { The lateral tendinous border goes to a } \\
\text { bump on the lateral tibia. While you stand, } \\
\text { the border appears to move forward }\end{array}$ \\
\hline
\end{tabular}

$C B=$ coracobrachialis $\mathrm{m}$., $\mathrm{LD}=$ latissimus dorsi $\mathrm{m} ., \mathrm{P}=$ pectoralis $\mathrm{m}$., $\mathrm{PIPJ}=$ proximal interphalangeal joint, $\mathbf{P M}=$ pectoralis minor $\mathbf{m}$., $\mathbf{S A}=$ serratus anterior $\mathbf{m}$., $T M=$ teres major $\mathrm{m}$. \#Chuck: a clamp formed by the thumb, index and middle finger as to hold a pen 


\section{Discussion and} Conclusions

As the survey results indicate, the participants' satisfaction with the novel, learner centered MSKASE method was rated highly for the three self-explored anatomical regions and by various specialists (mostly rheumatologists) and postgraduate trainees. While the effectiveness of the new method as compared with other living anatomy methods remains unproven, the results of the current survey suggest that given its general availability, lack of cost, and lack of intimacy barriers, MSKASE may be a useful adjunct to what is learned with other living anatomy pedagogies such as body painting (16), peer cross-examination (17), and peer-instructor cross-examination (18). Furthermore, with the COVID-19 pandemic, MSKASE could be a useful adjunct to imaging-based remote pedagogies.

Strengths of the current survey include a uniformly favorable perception of the method across specialties, training levels, and anatomical regions. Additionally, participants commented favorably on the opportunity to repeat the exercises anywhere and anytime and the absence of intimacy barriers.

There are several limitations to this survey. First, the idea to assess the participants' satisfaction with the method occurred to the authors close to the meeting, precluding a formal application to IRB approval. However, since no personal information was requested, data were de-identified, and participation was voluntary, no ethical barriers were infringed. Also, the scarcity of time precluded an early involvement of an expert in education in the study design. Another limitation was the unexpectedly large participant to instructor ratio compounded by the theater-type arrangement of the room. Ideally, the instructor, an examining table, and a screen should be at the front and the participants' chairs arranged in a horseshoe layout with a maximum of three rows and at least $1 \mathrm{~m}$ of free space between rows to facilitate the displacement of the instructors.

Despite these and other deficiencies, the results of the current survey are encouraging. They suggest that the method is well-received and worthy of further testing to aid current living anatomy pedagogies.

In summary, MSKASE is a novel learner-centered pedagogy that includes self-inspection, self-palpation, and self-perception. This method, which appears suitable for remote learning, was used for the first time at the 2018 PANLAR Meeting in Buenos Aires, Argentina. A voluntary, anonymous satisfaction poll conducted among a variety of participants revealed a high level of acceptance. 
Estai M, Bunt S. Best teaching practices in anatomy education: A critical review. Ann Anat.

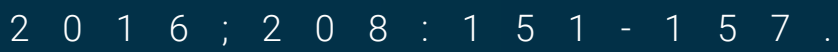
doi:10.1016/j.aanat.2016.02.010.

Wilson AB, Miller CH, Klein BA, Taylor MA, Goodwin M, Boyle EK, Brown K, Hoppe C, Lazarus M. A meta-analysis of anatomy laboratory pedagogies. Clin Anat. 2018;31(1):122-133. doi:10.1002/ca.22934

Triepels CPR, Koppes DM, Van Kuijk SMJ, Popeijus HE, Lamers WH, van Gorp T, Futterer JJ, Kruitwagen RFPM, Notten KJB. Medical students' perspective on training in anatomy. Ann Anat. 2018 May;217:60-65. doi: 10.1016/j.aanat.2018.01.006. Epub 2018 Mar 6. PMID: 29501634

Lo S, Abaker ASS, Quondamatteo F, Clancy J, Rea P, Marriott M, Chapman P. Use of a virtual 3D anterolateral thigh model in medical education: Augmentation and not replacement of traditional teaching? J Plast Reconstr Aesthet Surg. 2020;73:269-275. doi:10.1016/j.bjps.2019.09.034

McMenamin PG, McLachlan J, Wilson A, McBride JM, Pickering J, Evans DJR, Winkelmann A. Do we really need cadavers anymore to learn anatomy in undergraduate medicine? Med Teach. 2018
Oct;40(10):1020-1029.

doi: 10.1080/0142159X.2018.1485884. Epub 2018 Sep 28. PMID: 30265177.

Agius A, Stabile I. Undergraduate peer assisted learning tutors' performance in summative anatomy examinations: a pilot study. Int J Med Educ. 2018 Mar 30;9:93-98. doi: 10.5116/ijme.5aa3.e2a6. PMID: $29621744 ;$ PMCID: PMC5951778.

Wearn A, Bhoopatkar H. Experience of a peer physical examination policy within a New Zealand medical programme. Med Teach. 2014;36, 826-827.

Davis JJ, Wessner CE, Potts J, et al. Ultrasonography in undergraduate medical education: A systematic review. J Ultrasound Med. 2018;37:2667-2679. doi:10.1002/jum.14628

Hernández-Díaz C, Ventura-Ríos L, Gutiérrez M, et al. Ultrasonography in pediatric rheumatology in Latin America. Expanding the frontiers. Clin Rheumatol.

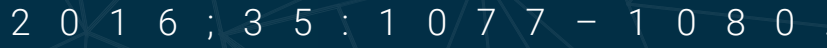
doi:10.1007/s10067-016-3217-x.

Mandl P, Baranauskaite A, Damjanov N, Hojnik M, Kurucz R, Nagy $O$ et al. Musculoskeletal ultrasonography in routine rheumatology practice: 
data from Central and Eastern European countries. Rheumatol Int. 2016;36:845-854. doi:10.1007/s00296-016-3442-2.

Villaseñor-Ovies P, Navarro-Zarza JE, Canoso JJ. The rheumatology physical examination: making clinical anatomy relevant. Clin Rheumatol. $\begin{array}{lllllllllllllll}2 & 0 & 2 & 0 & ; & 3 & 9 & : & 6 & 5 & 1 & - & 6 & 5 & 7\end{array}$. doi:10.1007/s10067-019-04725-9.

Hołda MK, Stefura T, Koziej M, Skomarovska O, Jasińska KA, Sałabun W, Klimek-Piotrowska W. Alarming decline in recognition of anatomical structures amongst medical students and physicians. Ann Anat. 2019;221:48-56. doi:10.1016/j.aanat.2018.09.004

Gilman-Morehead T. Surface Anatomy. New York, William Wood \& Co, 1905, (ii).

Canoso JJ, Saavedra MÁ, Pascual-Ramos V, Sánchez-Valencia MA, Kalish RA. Musculoskeletal anatomy by self-examination: A learner-centered method for students and practitioners of musculoskeletal medicine. Ann Anat. $\begin{array}{lllllllllllllll}2 & 0 & 2 & 0 & ; & 2 & 2 & 8 & : & 1 & 5 & 1 & 4 & 5 & 7 .\end{array}$. doi:10.1016/j.aanat.2019.151457.

Nguyen N, Mulla A, Nelson AJ, Wilson TD. Visuospatial anatomy comprehension: The role of spatial visualization ability and problem-solving strategies. Anat Sci Educ. 2014;7:280-288. doi:10.1002/ase. 1415 .

McLaughlin JE, Roth MT, Glatt DM, Gharkholonarehe
Davidson CA, Griffin LM, Esserman DA, Mumper RJ. The flipped classroom: a course redesign to foster learning and engagement in a health professions school. Acad Med.2014;89:236-243. doi:10.1097/ACM.0000000000000086.

McMenamin PG. Body painting as a tool in clinical anatomy teaching. Anat Sci Educ. 2008 Jul-Aug;1(4):139-44. doi: 10.1002/ase.32. PMID: 19177400.

Bergman EM, Sieben JM, Smailbegovic I, de Bruin AB, Scherpbier AJ, van der Vleuten CP. Constructive, collaborative, contextual, and self-directed learning in surface anatomy education. Anat Sci Educ. 2013;6:114-124. doi:10.1002/ase.1306

Kalish RA, Canoso JJ. Development of the seminar. Reumatol Clin. 2012 Dec-2013 Jan;8 Suppl 2:10-2. doi: 10.1016/j.reuma.2012.10.008. Epub 2012 Dec 8. PMID: 23228529. 
GLOBAL RHEUMATOLOGY 